REVIEW

\title{
Monogenic syndromes of abnormal glucose homeostasis: clinical review and relevance to the understanding of the pathology of insulin resistance and $\beta$ cell failure
}

\author{
J R Porter, T G Barrett
}

J Med Genet 2005;42:893-902. doi: 10.1136/jmg.2005.030791

Type 2 diabetes mellitus is caused by a combination of insulin resistance and $\beta$ cell failure. The polygenic nature of type 2 diabetes has made it difficult to study. Although many candidate genes for this condition have been suggested, in most cases association studies have been equivocal. Monogenic forms of diabetes have now been studied extensively, and the genetic basis of many of these syndromes has been elucidated, leading to greater understanding of the functions of the genes involved. Common variations in the genes causing monogenic disorders have been associated with susceptibility to type 2 diabetes in several populations and explain some of the linkage seen in genome-wide scans. Monogenic disorders are also helpful in understanding both normal and disordered glucose and insulin metabolism. Three main areas of defect contribute to diabetes: defects in insulin signalling leading to insulin resistance; defects of insulin secretion leading to hypoinsulinaemia; and apoptosis leading to decreased $\beta$ cell mass. These three pathological pathways are reviewed, focusing on rare genetic syndromes which have diabetes as a prominent feature. Apoptosis seems to be a final common pathway in both type 1 and type 2 diabetes. Study of rare forms of diabetes may help ion determining new therapeutic targets to preserve or increase $\beta$ cell mass and function.

See end of article for authors' affiliations

Correspondence to: Dr John R Porter, Diabetes Homecare Unit,

Birmingham Children's Hospital, Steelhouse Lane, Birmingham B4 6NH, UK; i.porter@bham.ac.uk

Received 6 January 2005 Revised version received 7 March 2005

Accepted for publication

11 March 2005
D abetes mellitus is a group of metabolic disorders characterised by hyperglycaemia and defective metabolism of lipids and glucose. Diabetes was estimated to affect 177 million people worldwide in 2000 and this figure is projected to increase to 300 million by 2025 . Most of this increase in diabetes is accounted for by an increased prevalence of type 2 diabetes.

Type 2 diabetes accounts for approximately $90 \%$ of cases of diabetes mellitus worldwide, ${ }^{1}$ and is characterised by a combination of defects in insulin secretion and insulin sensitivity. There is a significant genetic component to type 2 diabetes, but genome-wide scans and association studies have proved difficult to reproduce across different populations. ${ }^{2}$ Type 1 diabetes is characterised by autoimmune destruction of pancreatic $\beta$ cells, causing absolute insulin deficiency. The human leucocyte antigen (HLA) gene region contributes $42 \%$, and the insulin gene region $10 \%$ to the genetic susceptibility of type 1 diabetes. Other genes must therefore be involved in determining disease risk, each with a small effect but with a collective importance similar to the HLA region. ${ }^{3}$ Common to both type 1 and type 2 diabetes is progressive loss of $\beta$ cell function. In type 1 diabetes this $\beta$ cell loss is modulated by cytokines and is rapid; in type 2 diabetes progressive insulin resistance leading to increased demand on the $\beta$ cell, endoplasmic reticulum stress, lipotoxicity, and glucotoxicity cause a more gradual loss of $\beta$ cell function. The contribution of $\beta$ cell loss to type 2 diabetes in the human is still controversial. It has been clearly shown that in rodents the $\beta$ cell mass is variable throughout life, and that replication of mature $\beta$ cells is an important mechanism for increase in rodent $\beta$ cell mass, ${ }^{4}$ but for obvious reasons this has not been easy to show in humans. Recently, however, two papers from Japan and the USA have shown apparent loss of $\beta$ cell mass in human subjects at necropsy, interestingly showing differences in normal obese versus diabetic obese subjects. ${ }^{56}$ If, as seems likely, $\beta$ cell loss is common to type 1 and type 2 diabetes, the shared pathway for loss of $\beta$ cell mass in both forms is likely to be apoptosis, although the mechanisms underlying the initiation of apoptosis may differ. ${ }^{7}$

Maturity onset diabetes of the young (MODY) is a group of monogenic diabetes disorders causing $1-2 \%$ of cases of diabetes in the United Kingdom. ${ }^{8}$ Mutations in one of six MODY genes account for the diabetes in $85 \%$ of patients with MODY. ${ }^{2}$ Although the phenotypes of MODY syndromes differ, a $\beta$ cell defect is common to all. Approximately $5 \%$ of individuals with diabetes have the condition as part of a constellation of features or syndrome. ${ }^{10}$ These syndromes are usually monogenic and may cause insulin deficiency, insulin resistance, or both.

In the last 10 years extensive advances in our understanding of monogenic diabetes disorders have stemmed from tight clinical characterisation

Abbreviations: BSCL, Berardinelli-Seip congenital lipodystrophy; FARR, Friedreich's ataxia with retained lower limb reflexes; FFA, free fatty acids; GSIR, glucose stimulated insulin release; LOFA, late onset Friedreich's ataxia; MODY, maturity onset diabetes of the young; PERK, pancreatic endoplasmic reticulum kinase; PPAR $\gamma$, peroxisome proliferator activated receptor $\gamma$; RMS, Rabson-Mendenhall syndrome; TNDM, transient neonatal diabetes; TRMA, thiamine responsive megaloblastic anaemia 


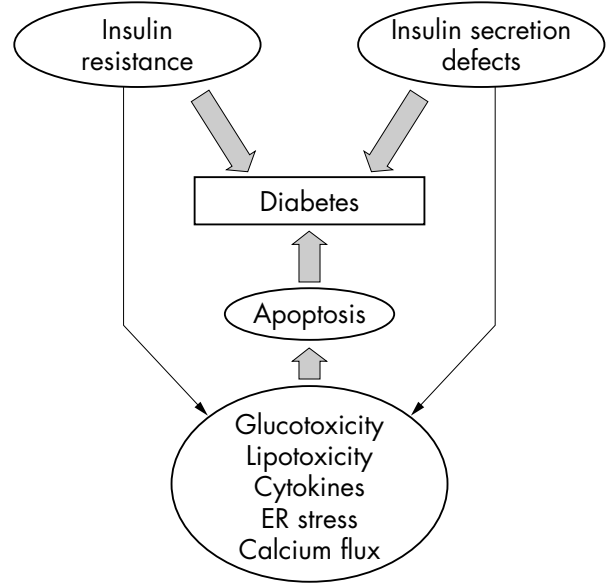

Figure 1 The interaction between insulin resistance, apoptosis, and insulin secretion defects in the aetiology of diabetes mellitus

and the discovery of genes for many of these syndromes. Identification of some of the MODY genes has revealed important components of the insulin secretion pathway, and has led to specific treatments for patients with MODY-for example, patients with HNF- $1 \alpha$ gene mutations have been found to be very sensitive to sulphonylurea drugs, and so may be able to stop insulin treatment. ${ }^{11} 12$
In this paper we will argue that the processes contributing to diabetes are threefold: insulin resistance and signalling problems; defects in insulin secretion; and diminished insulin secretion owing to reduction in $\beta$ cell mass by apoptosis (fig 1). We shall illustrate how rare syndromes of diabetes, and disorders of glucose homeostasis, have helped advance our knowledge of each mechanism, with specific examples (table 1).

\section{INSULIN RESISTANCE}

Insulin resistance is an important contributory factor to type 2 diabetes, and is particularly relevant with increasing obesity rates worldwide. In recent years it has been realised that adipose tissue is not an inert tissue as was once thought, but actively secretes hormones. ${ }^{13}$ Peroxisome proliferator activated receptor $\gamma$ has been at the forefront of our understanding of this new endocrine organ. Familial partial lipodystrophy and insulin receptor abnormalities have helped us understand more about the pathways for insulin signalling, and how they can be disrupted.

Peroxisome proliferator activated receptor $\gamma$ (PPAR $\gamma$ ) PPAR $\gamma$ (OMIM 601487) is a transcription factor predominantly expressed in adipose tissue, ${ }^{14}$ but has also been shown to be expressed in small quantities in liver, muscle, and pancreas. ${ }^{15}$ It has become clear that PPAR $\gamma$ plays a vital role in the regulation of body fat distribution and insulin sensitivity, acting to promote energy storage as a thrifty response. Thiazolidinediones are a class of antidiabetic drugs

\begin{tabular}{|c|c|c|c|}
\hline $\begin{array}{l}\text { Presumed } \\
\text { mechanism }\end{array}$ & Condition & Gene and location & Other features \\
\hline \multirow[t]{3}{*}{ Insulin resistance } & PPAR $\gamma$ & PPAR $\gamma(3 p 25)$ & $\begin{array}{l}\text { Hypertension } \\
\text { - Hypertriglyceridaemia }\end{array}$ \\
\hline & $\begin{array}{l}\text { Congenital generalised } \\
\text { lipodystrophy }\end{array}$ & $\begin{array}{l}\text { BSCL1 (9q34.3) } \\
\text { BSCL2 (1 } 1 q 13)\end{array}$ & $\begin{array}{l}\text { - Congenital lipodystrophy } \\
\text { - Hypertriglyceridaemia } \\
\text { - Hyperandrogenism }\end{array}$ \\
\hline & Insulin receptor defects & INSR (19p13.2) & $\begin{array}{l}\text { - Fasting hypoglycaemia } \\
\text { - Postprandial hyperglycaemia } \\
\text { - Pipodystrophy and dysmorphism } \\
\text { - Progressive diabetes }\end{array}$ \\
\hline \multirow[t]{2}{*}{$\begin{array}{l}\text { Insulin secretion } \\
\text { defects }\end{array}$} & Glucokinase defects & GCK (7p15-p13) & $\begin{array}{l}\text { - } \text { MODY } \\
- \text { PNDM } \\
- \text { PHHI }\end{array}$ \\
\hline & Kir6.2 defects & KCNJ11 (11p15.1) & $\begin{array}{l}\text { - Developmental delay } \\
\text { - Epilepsy } \\
\text { PHHI }\end{array}$ \\
\hline \multirow[t]{5}{*}{ Apoptosis } & Wolcott-Rallison & EIF2AK3 (2p12) & $\begin{array}{l}\text { - Epiphyseal dysplasia } \\
\text { - Developmental delay } \\
\text { - Renal/hepatic impairment }\end{array}$ \\
\hline & Wolfram & $\begin{array}{l}\text { WFS1 (4p16.1) } \\
\text { ?WFS2 (4q22-24) }\end{array}$ & $\begin{array}{l}\text { - Deafness } \\
\text { - Optic atrophy } \\
\text { - Diabetes insipidus }\end{array}$ \\
\hline & Friedreich's ataxia & FRDAl (9q13) & $\begin{array}{l}\text { - Ataxia } \\
\text { - Pyramidal signs } \\
\text { - Loss of leg reflexes }\end{array}$ \\
\hline & Werner syndrome & WRN (8p12-11.2) & $\begin{array}{l}\text { - Premature aging } \\
\text { - Sarcomas }\end{array}$ \\
\hline & $\begin{array}{l}\text { Thiamine responsive } \\
\text { megaloblastic anaemia }\end{array}$ & SLC19A2 (1q23.3) & - Megaloblastic anaemia \\
\hline
\end{tabular}

GCK, glucokinase; MODY, maturity onset diabetes of the young; PHHI, persistent hyperinsulinaemic hypoglycaemia of infancy; PNDM, permanent neonatal diabetes. 
that act through PPAR $\gamma$ stimulation to improve hypertension, blood glucose control, and insulin sensitivity in patients with type 2 diabetes. ${ }^{16}$ The complex effects of PPAR $\gamma$ are modulated by several ligands (most notably the thiazolidinediones), the tissue expression of PPAR $\gamma$, and the specific activity of PPAR $\gamma$. Our understanding of PPAR $\gamma$ effects has been advanced by study of mutations in the PPAR $\gamma$ gene (PPARG) in humans, tissue selective knockout of PPAR $\gamma$, and study of the effects of PPAR $\gamma$ ligands on body composition and insulin sensitivity.

The effects of mutations in PPARG in humans illustrate the complexity of the role of PPAR $\gamma$. An activating mutation in PPARG is associated with obesity but preserved insulin sensitivity. ${ }^{17}$ Inactivating mutations in PPARG cause a form of lipodystrophy with insulin resistance. ${ }^{18-20}$ These findings suggest that increasing activity of PPAR $\gamma$ is inversely proportional to insulin sensitivity, albeit at the expense of weight gain, and indeed this is the effect of thiazolidinediones. ${ }^{21}$ However, a common polymorphism in PPARG (Prol2Ala), which decreases the activity of PPAR $\gamma$, is associated with high insulin sensitivity and decreased susceptibility to type 2 diabetes. ${ }^{22}{ }^{23}$ How can activation and attenuation of PPAR $\gamma$ both be associated with improved insulin sensitivity? The solution may be twofold. First, stimulation of PPAR $\gamma$ causes small adipocyte proliferation ${ }^{24}$ while loss of function of PPAR $\gamma$ causes decreased lipogenesis and increased fatty acid oxidation ${ }^{24}$; both processes result in decreased adipocyte hypertrophy and decreased free fatty acids, and hence increased insulin sensitivity. ${ }^{24}$ Second, PPAR $\gamma$ activity relates linearly to fat mass accretion but not to insulin sensitivity, ${ }^{25}$ suggesting that other tissues are involved in the regulation of insulin sensitivity. Murine models have allowed elimination of PPAR $\gamma$ from selected tissues to explore this suggestion further.

Murine models of non-specific PPARG mutations compare well with human phenotypes. ${ }^{26}{ }^{27}$ Adipose tissue specific PPAR $\gamma$ knockout mice have severe lipodystrophy ${ }^{28}{ }^{29}$ but normal glucose tolerance. Knockout of liver PPAR $\gamma$ causes an increase of free fatty acids (FFA), increased adiposity, and insulin resistance. ${ }^{30}$ Muscle knockout of PPAR $\gamma$ leads to raised FFA, adiposity, and insulin resistance. ${ }^{31}{ }^{32}$ These results indicate that the interplay between all three tissues is important in maintaining glucose and lipid homeostasis. The absolute importance of adipose tissue in insulin sensitivity is illustrated by the fact that thiazolidinediones cause increased insulin sensitivity in both liver and muscle knockouts but not the adipose tissue knockout mouse, although the blood glucose response remains.

The selective adipose tissue PPAR $\gamma-/-$ mouse knockout shows that thiazolidinedione effects on glucose (but not insulin resistance) are independent of adipose tissue. PPAR $\gamma$ activation reduces islet cell hyperplasia ${ }^{33}$ and is also thought to reduce islet cell apoptosis-in part by reducing lipid deposition and inhibiting nitric oxide synthesis in the $\beta$ cell and in part by reducing free fatty acids by repartitioning adipose tissue and stimulating production of small insulin sensitive adipocytes. ${ }^{15}$ PPAR $\gamma$ has also been shown to upregulate glucokinase ${ }^{34}$ and the Glut 2 glucose transporter, ${ }^{35}$ key components in glucose sensing, in both pancreas and liver, thus increasing insulin release and hepatic insulin sensitivity.

PPAR $\gamma$ appears to play a vital role in fat mass accretion, and independently in the regulation of insulin sensitivity. Increasing understanding of PPAR $\gamma$ has led to attempts to modulate rather than absolutely stimulate PPAR $\gamma$. Thiazolidinediones are potent PPAR $\gamma$ agonists which are effective at lowering blood glucose and improving insulin resistance in patients with impaired glucose tolerance or type 2 diabetes, ${ }^{16}$ and seem to alter fat distribution so that subcutaneous rather than visceral adipose tissue is laid down. ${ }^{21} 3637$ Weight gain on thiazolidinediones can be a problem, however, and experiments with other PPAR $\gamma$ ligands have shown that partial agonists and antagonists of PPAR $\gamma$ can produce the effects on glucose tolerance and insulin resistance without the increase in adipose tissue. ${ }^{38-40}$ These agents may prove to be extremely useful antidiabetic drugs.

\section{Berardinelli-Seip congenital lipodystrophy/ congenital generalised lipodystrophy}

Berardinelli-Seip congenital lipodystrophy (BSCL; OMIM 269700 ) is a rare disorder characterised by congenital absence of subcutaneous and visceral fat, with severe insulin resistance that progresses to diabetes in early adolescence. ${ }^{41}$ Other features of the condition are acanthosis nigricans, hypertriglyceridaemia, fatty liver, virilisation, and cardiomyopathy. ${ }^{41}$ The condition is autosomal recessive; two genes have been isolated by positional cloning which account for $82 \%$ of cases.

The first, BSCLl on chromosome 9q34, encodes 1acylglycerol-3-phosphate-O-acyltransferase 2 (AGPAT2). ${ }^{42}$ AGPAT2 catalyses an important step in the triacylglycerol pathway. AGPAT2 regulates conversion of lysophosphatidic acid to phosphatidic acid. Phosphatidic acid is the substrate for phosphatidylinositol production. Phosphatidylinositol is an important messenger in insulin signalling pathways and so disruption of its production may be the cause of insulin resistance in BSCL. ${ }^{43}$

The second locus, BSCL2 on $11 \mathrm{q1} 3,{ }^{44}$ maps to a gene Gng31g ,which encodes a protein, seipin, of unknown function. Unlike AGPAT2, Gng3lg is widely expressed in the brain. Patients with Gng3lg mutations have learning difficulties $(80 \%)$, are three times more likely to suffer from cardiomyopathy, have diabetes with onset at a significantly earlier age, and may be at risk of early death when compared with patients with mutations in AGPAT2 ${ }^{41}{ }^{45}$ There is poor genotype to phenotype correlation in BSCL, suggesting that alternative environmental or genetic influences may be important. ${ }^{46}$

\section{Insulin receptor defects}

Insulin receptor defects produce a spectrum of insulin resistant phenotypes, ${ }^{47}$ ranging from the severe Donohue syndrome (OMIM 246200) to the relatively mild insulin resistance type A (OMIM 147670). Patients with Donohue syndrome (previously known as leprechaunism) have severe intrauterine growth restriction and hyperinsulinaemia with abnormal glucose homeostasis, characterised by fasting hypoglycaemia and postprandial hyperglycaemia, ${ }^{48}$ facial dysmorphism, reduced subcutaneous fat, and protuberant abdomen. Patients have $<10 \%$ of wild type insulin binding, and either premature stop mutations or mutations in the extracellular domain of the receptor. These defects are associated with death occurring before two years of age. ${ }^{48}$ In contrast, patients with Rabson-Mendenhall syndrome (RMS) have mutations in the intracellular domain of the receptor, and insulin binding at levels of up to $25 \%$ of normal. ${ }^{48}$ RMS can be distinguished from Donohue syndrome by the presence of dysplastic gums and teeth, thickened nails, and hirsutism. Children with RMS develop progressive ketoacidotic diabetes, most dying before adolescence. ${ }^{48}$ Type A insulin resistance is associated with hirsutism and hyperandrogenism in slim individuals, and with survival well into adulthood. ${ }^{49}$

Insulin affinity studies had shown a defect in insulin affinity in these syndromes before the receptor gene was isolated. ${ }^{50}$ Following discovery of the insulin receptor gene on chromosome 19p, homozygous and compound heterozygous mutations were found in several individuals with severe 
insulin resistance. ${ }^{47}$ These have varied effects on the insulin receptor. Taylor classified these mutations into five classes: those that impair synthesis of receptors; those that impair transport of receptors to the cell membrane; those that decrease receptor affinity for insulin; those that reduce the tyrosine kinase activity of the receptor intracellular domain; and those that accelerate receptor degradation. ${ }^{47}$ Initially it was thought that the presence of some insulin receptors was vital for intrauterine survival, but patients with homozygous null mutations have since been described. ${ }^{48} 51$ The finding that a heterozygote father of one patient with Donohue syndrome was insulin resistant was of interest for the wider population, but the very rarity of Donohue syndrome mitigates against heterozygous mutations being a common cause of type 2 diabetes. ${ }^{52}$ The latest research in these syndromes has shown, by gene expression studies, significant alterations in the expression of genes encoding growth factors (including insulin-like growth factors) and apoptotic factors in patients with Donohue syndrome. ${ }^{53}$ Further work in this area may help link the contributions of insulin resistance and loss of $\beta$ cell mass in diabetes pathology.

\section{INSULIN SECRETION DEFECTS}

One of the successes of the 1990s was the unravelling of the genetics of maturity onset diabetes of the young. While most of the genes found for MODY have been transcription factors, ${ }^{9}$ the glucokinase gene encodes a key regulatory enzyme, and a newly found neonatal diabetes gene KCNJIl encodes Kir6.2, a component of the ATP sensitive potassium channel. Glucokinase and Kir6.2 are key components in the $\beta$ cell insulin secretion pathway. What is particularly interesting is that both activating and inactivating mutations in these genes have been found, and the contrasting phenotypes have led to greater understanding of the molecular biology of the $\beta$ cell and also to guidelines for treatment in patients with these conditions.

1. Thiamine responsive megaloblastic anaemia

2. Glucokinase defects

3. Friedreich's ataxia

4. Kir6.2 neonatal diabetes

5. Wolcott-Rallison syndrome

6. Wolfram syndrome

7. Werner syndrome

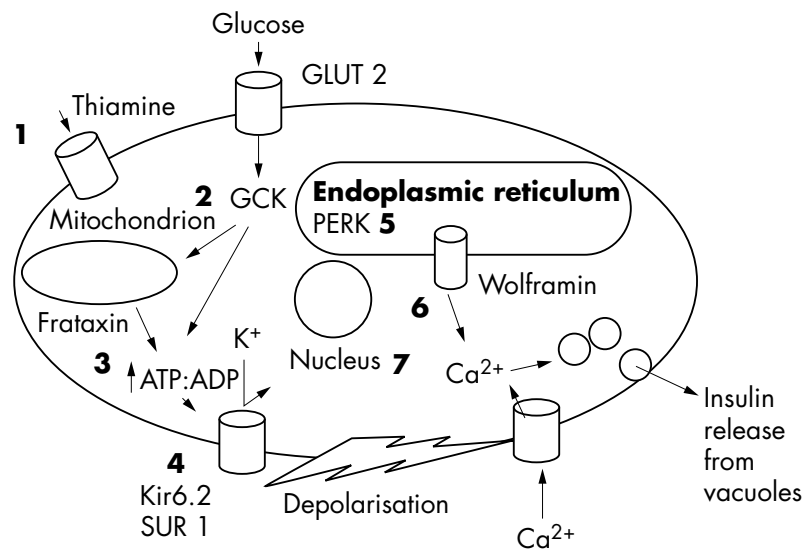

Figure 2 Schematic of the current theory of glucose stimulated insulin release from the pancreatic $\beta$ cell, showing the proposed sites of action of inherited diabetes. Current theory of insulin release: Glucose enters the $\beta$ cell through the GLUT 2 transporter. Glucose is metabolised in the glycolytic pathway by enzymes including glucokinase (GCK) to produce ATP. Rising intracellular ATP:ADP closes the ATP sensitive potassium channel Kir6.2/SUR1, causing membrane depolarisation. Voltage gated calcium channels open and intracellular calcium flux triggers insulin release.

\section{Glucokinase defects}

Glucokinase (GCK) is a key hexokinase enzyme involved in modulation of glucose stimulated insulin release (GSIR). The high $\mathrm{S}_{0.5}$, cooperativity with glucose, and lack of inhibition by its product glucose-6-phosphate make it the rate limiting step in GSIR and thus allow it to act as a glucose sensor for the $\beta$ cell. ${ }^{54}$ Glucose enters the cell by way of the GLUT 2 transporter and is then metabolised by glucokinase as the first step of the glycolysis pathway that generates ATP necessary for insulin exocytosis (fig 2). Given the central role of glucokinase it was a prime candidate gene for monogenic diabetes, and heterozygous ${ }^{55} 56$ and homozygous and compound heterozygous ${ }^{57}$ inactivating mutations have been found (OMIM *138079) that cause diabetes, as well as heterozygous activating mutations that cause hyperinsulinism. ${ }^{59}$

Heterozygous inactivating mutations of glucokinase cause a subtype of maturity onset diabetes of the young (MODY2/ GCK-MODY). There are now over 190 published mutations in glucokinase in different ethnic populations causing MODY2. ${ }^{54}$ MODY2 is a mild form of hyperglycaemia/diabetes; clinically, patients are often asymptomatic and are classically found to have diabetes coincidentally, most commonly during pregnancy. The defect in glucokinase leads to a rise in the plasma level of glucose at which insulin secretion is triggered, from a normal value of $\sim 5 \mathrm{mmol} / \mathrm{l}$. Compensation by the wild type allele means that the rise in GSIR in glucokinase is limited to $\sim 7 \mathrm{mmol} / \mathrm{l}$ in all cases, equating to a fasting plasma glucose of $6-8 \mathrm{mmol} / \mathrm{l} .^{54}$ This raised fasting glucose remains constant throughout life, and can be managed by basic dietary measures alone, in contrast to the transcription factor MODY types where fasting glucose rises with age resulting in complications in the long term. ${ }^{60}$

Homozygous or compound heterozygous inactivating mutations of glucokinase cause permanent neonatal diabetes. ${ }^{57} 58$ This is a very rare condition and shows evidence of genotype-phenotype correlation. Mutations in the substrate binding site cause severe increases in the GSIR, resulting in fasting glucose levels of $50 \mathrm{mmol} / \mathrm{l}$ or more. Unlike MODY2, the diabetes is insulin dependent, requiring full insulin replacement. $^{58}$

Heterozygous activating mutations in glucokinase cause persistent hyperinsulinaemic hypoglycaemia of infancy (PHHI).$^{59} \mathrm{PHHI}$ is a heterogeneous disorder caused by defects in any one of Kir6. $2^{61}$ or SUR ${ }^{62}$ (components of the ATP sensitive potassium channel of the $\beta$ cell), GLUDl ${ }^{63}$ (an enzyme in the amino acid metabolism pathway in the $\beta$ cell), or glucokinase. ${ }^{59}$ Unlike PHHI caused by abnormalities of Kir6.2/SUR1, in GCK-PHHI there is still a relation between glucose level and insulin production, but it is reset to a lower GSIR than normal. ${ }^{54}$ GCK-PHHI responds well to diazoxide which acts to open the potassium channels and inhibit insulin release. GCK-PHHI is an alteration in glucose homeostasis that can range from mild hypoglycaemia, treated in some cases by regular eating alone, to severe persistent hypoglycaemia. ${ }^{64}$

These different mutations in the glucokinase gene cause three separate phenotypes-MODY, permanent neonatal diabetes, and PHHI-each illustrating aspects of glucose stimulated insulin release and providing new areas for targeting with drug treatments in diabetes.

\section{Kir6.2 defects (OMIM *600937)}

The $\beta$ cell potassium channel is intimately involved in the regulation of insulin secretion and is an octomeric complex composed of four inwardly rectifying potassium channels (Kir6.2), and four sulphonylurea receptor subunits (SUR1). ${ }^{65}$ Kir6.2 binds ATP to close the channel, and magnesium nucleotides bind to SURI causing activation of the channel. ${ }^{65}$ 
In the fed state, high intracellular glucose generates ATP through glycolysis and closes the potassium channel, leading to cell membrane depolarisation and insulin release (fig 2). Fasting lowers the intracellular ATP:ADP ratio, resulting in opening of the potassium channel and inhibition of insulin secretion. ${ }^{6}{ }^{\text {Both Kir6.2 }}$ and SUR1 are vital for the correct regulation of insulin secretion, and inactivating mutations in the genes encoding both have been shown to cause autosomal recessive PHHI, characterised by complete loss of GSIR and poor response to diazoxide..$^{62}$

Interest in the role of Kir6.2 in insulin secretion led to consideration of the gene for Kir6.2 (KCNJI1) as a candidate gene for type 2 diabetes. An association study in 2486 UK subjects showed an association with type 2 diabetes and the E23K allele of KCNJ11. ${ }^{54}$ Following the finding that glucokinase mutations can cause both diabetes and hyperinsulinaemia, mutation analysis showed activating mutations in the KCNJ1l gene encoding Kir6.2 in $\sim 34 \%$ of permanent neonatal diabetes cases. ${ }^{66}$ This raised the possibility of treatment with oral sulphonylureas rather than insulin injection, and has proved successful in some patients, albeit with short follow up to date. ${ }^{67}$ Some cases of neonatal diabetes with KCNJIl mutations have also shown mild dysmorphism, developmental delay, and epilepsy. ${ }^{66}{ }^{68}$

\section{APOPTOSIS}

One of the evolutionary compromises the $\beta$ cell appears to have accepted is increased sensitivity to apoptosis; indeed it appears that the balance between $\beta$ cell loss and replication is one of the ways in which glucose homeostasis is maintained in the normal individual, the overall $\beta$ cell mass being remarkably variable in response to the demands of pregnancy or obesity. ${ }^{69}$ Moreover the $\beta$ cell deals routinely with substrates and byproducts that are lethal to the cell in raised concentrations. Glucotoxicity, lipid toxicity, free radicals, and cytokines have all been implicated as factors initiating apoptosis. ${ }^{70}$ Unregulated apoptosis appears to be a final common pathway for the loss of $\beta$ cell mass in type 1 diabetes, type 2 diabetes, ${ }^{70}$ and possibly MODY. ${ }^{71}$ The development of a transgenic mouse model of transient neonatal diabetes (TNDM), in which the human transient neonatal diabetes locus TNDM2 9 is expressed, ${ }^{72}$ has suggested that apoptosis may be an important feature in diabetes development in this disease as well. Humans with TNDM present with diabetes at a median age of three days, but then recover to normal glucose homeostasis at a median of 12 weeks. $^{73}$ Follow up has shown that many of these individuals then develop permanent diabetes as adolescents. ${ }^{73}$ Fetal transgenic mice have reduced $\beta$ cell numbers at day 14 of gestation compared with normal mice, but have increased $\beta$ cell production resulting in normal numbers of $\beta$ cells by term, and greater than normal $\beta$ cell numbers as juveniles. However, as adults the transgenic mice have the same number of $\beta$ cells as their normal peers, suggesting $\beta$ cell loss as adolescents, and this $\beta$ cell mass is coupled with impaired glucose tolerance. ${ }^{72}$ TNDM29 contains at least one gene, zinc finger protein, that regulates apoptosis and cell cycle arrest (ZAC) and which is a potent apoptotic factor. ${ }^{74}$ This model suggests that the balance between $\beta$ cell neogenesis, apoptosis, and function is key to the remitting and relapsing nature of TNDM.

Although initially it was thought that type 1 diabetes was caused by autoimmune reactions and type 2 by non-immune processes, this division now seems oversimplistic. While cytokine mediated apoptotic pathways, chiefly tumour necrosis factor $\alpha(\mathrm{TNF} \alpha)$ and interleukin $1 \beta$ (IL1 $\beta$ ), have been shown to be the leading cause of $\beta$ cell loss in type 1 diabetes, ${ }^{75}$ inflammatory responses also seem to have a bearing on type 2 diabetes. Glucose toxicity to islet cells in
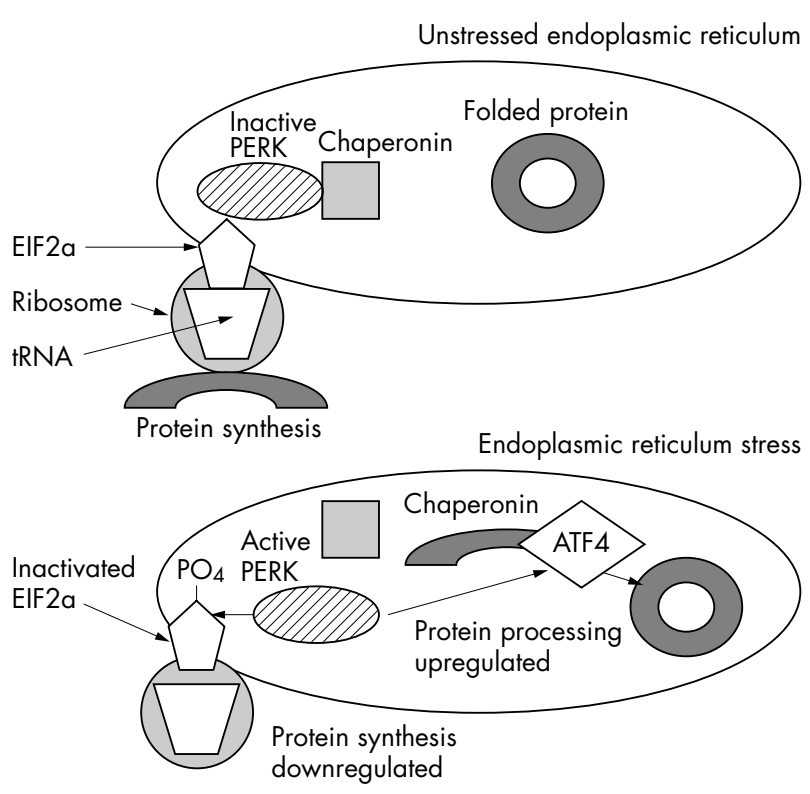

Figure 3 Schematic of the role of pancreatic endoplasmic reticulum kinase (PERK) in the response to endoplasmic reticulum stress. Build up of unfolded protein causes PERK to dissociate from inactivating chaperonins. Activated PERK then phosphorylates EIF2 $\alpha$ and activates ATF4, causing reduction of protein synthesis and increase protein processing.

high concentrations seems to be mediated by ILl $\beta$ secreted by the islet cell itself $^{76}$ and probably contributes to both type 1 and type 2 diabetes. Some overlap between type 1 and type 2 diabetogenic processes appears to be the cause of the ill defined entity of latent autoimmune diabetes of the adult. Many rare forms of diabetes have apoptosis as an underlying cause, and we will discuss five different mechanisms proposed as causes for $\beta$ cell apoptosis: Wolcott-Rallison syndrome (endoplasmic reticulum stress); Wolfram syndrome (calcium signalling); Friedreich's ataxia (mitochondria dysfunction); Werner's syndrome (deficient DNA repair); and thiamine responsive megaloblastic anaemia ${ }^{69}$ (defective ribose synthesis).

\section{Wolcott-Rallison syndrome}

Wolcott-Rallison syndrome (OMIM 226980) is a rare autosomal recessive condition characterised by extremely early onset diabetes, epiphyseal dysplasia, renal impairment, acute hepatic failure, and developmental delay. Diabetes presents in infancy and is associated with $\beta$ cell loss, leading to insulin deficiency without autoimmune pathology. ${ }^{77}$ The WolcottRallison gene EIF2AK3, ${ }^{78}$ which codes for eukaryotic initiation factor $2 \alpha$ kinase 3, is also known as the pancreatic endoplasmic reticulum kinase (EIF2AK3/PERK). ${ }^{78}$ PERK regulates the cellular response to endoplasmic reticulum stress. ${ }^{79}$ The latter is caused when an imbalance between protein synthesis and processing occurs, such that unfolded protein builds up in the endoplasmic reticulum. This occurs commonly in secretory cells, and in the normal state is controlled by three main processes: first, protein synthesis is reduced; second, protein processing and removal of excess unfolded protein is upregulated; and third, apoptosis occurs. ${ }^{79}$ PERK is a vital component of the control of these processes (fig 3). PERK is normally bound in the endoplasmic reticulum to chaperonins that inactivate it. ${ }^{80}$ These disassociate from PERK when unfolded protein levels rise in the endoplasmic reticulum. PERK kinase activity allows phosphorylation of eukaryotic initiation factor $2 \alpha$ (EIF2 $\alpha)$, a complex recruiting tRNA to ribosomes. This causes a 
reduction in EIF $2 \alpha$ activity and thus a suppression of protein synthesis. ${ }^{79}$ PERK is also crucially involved in the second step of the cellular response to endoplasmic reticulum stress-the upregulation of translation of activating transcription factor 4 (ATF4), which is involved in protein processing. ${ }^{79}$ It can be predicted that loss of PERK activity will lead to uncontrolled apoptosis.

PERK knockout mice are born with apparently normal islet cells, but undergo islet cell loss over the first weeks of life culminating in the development of lethal diabetes. ${ }^{79}$ Interestingly PERK - /- mice do not show features of hepatic dysfunction or impaired gluconeogenesis seen in Wolcott-Rallison patients, but this phenotype is seen in mice with a defective EIF2 $\alpha$ that is resistant to phosphorylation. PERK is one of four EIF kinases. These findings suggest that in mice, unlike humans, hepatic EIF $2 \alpha$ is not exclusively phosphorylated by PERK. ${ }^{79}$

EIF2AK3 is expressed in islet cells, liver, bone, glomerular tissue, and lung in humans, ${ }^{81}$ and loss of kinase activity has been demonstrated in patients with Wolcott-Rallison syndrome. ${ }^{82}$ Initial findings indicate that EIF2AK3 is not a common diabetes susceptibility gene in the general diabetes population, ${ }^{83}$ but study of Wolcott-Rallison syndrome has highlighted endoplasmic reticulum stress as an important potential factor in the development of diabetes.

\section{Wolfram syndrome}

Wolfram syndrome (sometimes known by the acronym DIDMOAD) (OMIM 222300) is an autosomal recessive syndrome in which the association of diabetes with progressive optic atrophy under 16 years of age is diagnostic. ${ }^{84}$ Other features are bilateral sensorineural deafness, diabetes insipidus, dilated renal tracts, and truncal ataxia or more protean neurological signs, with the complete phenotype seen in $75 \%$ of patients. ${ }^{84}$ The diabetes is non-autoimmune and insulin deficient and presents at a mean age of six years. Patients require insulin treatment from the time of diagnosis. The median age of death in Wolfram syndrome is 30 years and development of the full phenotype is seen with increasing age. ${ }^{85} \mathrm{~A}$ gene for Wolfram syndrome (WFS1) was discovered in 1998 on chromosome 4p by two separate groups, using positional cloning ${ }^{86}$ and candidate gene approaches. ${ }^{87}$ Mutations in WFS I are present in at least $90 \%$ of patients with clinical Wolfram syndrome. ${ }^{87}$ WFS1 encodes a protein termed wolframin that has nine putative transmembrane segments; it is exclusively located in the endoplasmic reticulum in the $\mathrm{rat}^{88}$ and appears either to modulate the action of calcium channels in the endoplasmic reticulum or to actually be a calcium channel itself. Calcium fluxes have been shown to be important in intracellular signalling and in the prevention of apoptosis. It has been proposed that loss of wolframin expression leads to apoptosis in the pancreatic $\beta$ cells and the neurones of the central nervous system, producing the characteristic Wolfram phenotype. $^{88}$

Very recently, Japanese researchers have disrupted the WFS-1 gene in mice. ${ }^{89}$ They have shown that mutant mice have a $23 \%$ reduction in glucose stimulated insulin secretion, and develop diabetes. Insulin secretion mediated directly by calcium release from the endoplasmic reticulum was also reduced in these mice. When wolframin was re-expressed in islets from mutant animals, glucose stimulated insulin release and insulin release mediated by calcium release in the endoplasmic reticulum were both restored. In addition, isolated islets from mutant mice showed higher than normal susceptibility to apoptosis when exposed to agents inducing endoplasmic reticulum stress. Wolframin seems to be vital for both calcium mediated insulin release in the endoplasmic reticulum and the prevention of apoptosis induced by endoplasmic reticulum stress.

As with other syndromes discussed in this review, WFS-1 has been suggested as a susceptibility gene in type 2 diabetes. In a study of 327 individuals with type 2 diabetes and 357 controls, the R456-H61l haplotype was significantly more frequent in type 2 subjects. ${ }^{90}$ Further studies in other populations will be required to prove the significance of this finding.

\section{Friedreich's ataxia}

Friedreich's ataxia (OMIM 229300) is an inherited neurodegenerative disorder. Patients usually present with four limb ataxia, associated with cerebellar signs, absent lower limb reflexes, sensory loss, and pyramidal signs before the age of 20 , and the disease is progressive. ${ }^{91}$ Diabetes mellitus is seen in around $10 \%$ of patients. Clinically there are three subforms of Friedreich's ataxia-classical disease, late onset disease (onset $>20$ years)(LOFA), and Friedreich's ataxia with retained lower limb reflexes (FARR). ${ }^{91}$ The pattern of inheritance in Friedreich's ataxia is autosomal recessive, and the mutated gene FRDAl has been mapped to chromosome 9q. ${ }^{92}$ FRDAl encodes a protein frataxin which is localised to mitochondria. ${ }^{93}$ The genetic defect in most patients is homozygous areas of trinucleotide (GAA) repeat expansion in exon 1 of FRDA, $^{94}$ but some patients are compound heterozygotes with an expanded allele and a point mutation in FRDAl. ${ }^{94}$ Most normal individuals have 7 to 22 repeats in FRDAl, while patients with Friedreich's ataxia have 200 to $900+{ }^{94}$ There is a genotype-phenotype correlation: individuals with less than 500 repeats are significantly less likely to develop cardiomyopathy and more likely to have the milder disease variants LOFA and FARR, ${ }^{91}$ but there is no relation between repeat length and diabetes. ${ }^{95}$ Compound heterozygotes are more likely than homozygotes to have a milder atypical Friedreich phenotype. ${ }^{95} 96$ Friedreich's ataxia is the first known recessive trinucleotide repeat disease and, unlike dominant examples, lacks genetic anticipation. It does resemble other trinucleotide repeat diseases in that paternal expanded alleles tend to reduce in size during transmission, consistent with selection pressure for spermatozoa with shorter repeats; however, unlike myotonic dystrophy where maternal repeats expand with each generation, maternal repeats in Friedreich's ataxia can expand or reduce with transmission. ${ }^{91}$

The areas of expanded repeats in Friedreich's ataxia can form a unique structure called sticky DNA. ${ }^{97}$ This association of two triplet expansion segments has been shown to reduce frataxin transcription by binding to the DNA and blocking the action of RNA polymerase. ${ }^{97}$ Frataxin is localised in human and other species to mitochondria, and in vivo, deficits in mitochondrial function can be seen in patients with Friedreich's ataxia. ${ }^{98}$ Fibroblasts from Friedreich patients show increased sensitivity to oxidative stress from hydrogen peroxide or iron, which can be reversed by iron chelators $^{99}$ or frataxin transfection. ${ }^{100}$ In many cell lines, oxidative stress causes increased intracellular calcium levels and apoptosis. Calcium chelators and apoptosis inhibitors preferentially rescue Friedreich fibroblasts, suggesting that uncontrolled apoptosis maybe the cause for the manifestations of Friedreich's ataxia. ${ }^{99}$ Finally, lack of frataxin in knockout mice has been shown to be associated with progressive loss of $\beta$ cell mass leading to diabetes with reduced insulin secretory capacity. ${ }^{101}$

The association of diabetes in Friedreich's ataxia and the asymptomatic carriage of expanded repeats in heterozygotes has led to suggestions that heterozygote status for this disease might be an important cause of susceptibility to type 2 diabetes. Heterozygous carriers of a triplet expansion are 
insulin resistant ${ }^{102}$ and those with impaired glucose tolerance have altered $\beta$ cell characteristics. ${ }^{103}$ Studies in German and American populations have suggested an association with type 2 diabetes, ${ }^{104}$ but this has not been borne out in other European populations, ${ }^{103}{ }^{105}$ suggesting that Friedreich heterozygote status is not an important risk factor for type 2 diabetes.

\section{Werner syndrome}

Werner syndrome (OMIM 277700) is an autosomal recessive disorder characterised by the appearance of premature aging and the development of age associated disorders such as type 2 diabetes mellitus (penetrance up to $90 \%$ ), ${ }^{106}$ osteoporosis, atherosclerosis, and susceptibility to neoplasms; particularly sarcomas. In Werner syndrome, sarcomas are as prevalent as carcinomas, whereas in the normal population carcinomas are 10 times more common. ${ }^{106}$ Patients with Werner syndrome become insulin resistant, but initially maintain glycaemia by hypersecretion of insulin. When insulin secretion becomes compromised diabetes develops. ${ }^{107}$ In the third decade Werner patients begin to show signs of aging, with hair loss and skin atrophy. ${ }^{106} 108$

The gene for Werner syndrome (WRN) was discovered in 1996, ${ }^{109}$ and its product has two functions: as a DNA helicase and as an exonuclease. WRN protein is located in the nucleus or nucleolus depending on cell type. ${ }^{108}$ All mutations in Werner syndrome result in truncation of the protein and loss of the nuclear localisation signal on the C-terminal end of the protein $^{110}$; thus transport of the protein into the nucleus seems to be critical for the protein function.

Study of proteins that interact with it has shed some light on the function of WRN. WRN interacts with replication protein A (RPA), topoisomerase 1, proliferating cell nuclear antigen, and DNA polymerase $\delta(\operatorname{pol} \delta),{ }^{108}$ to enhance polymerase activity. ${ }^{11}$ WRN enables pol $\delta$ to continue DNA synthesis despite hairpin and tetraplex structures formed by trinucleotide repeats, which would normally stop synthesis. ${ }^{112}$ WRN appears to aid DNA replication and repair by unwinding potential blocks in the process. This hypothesis is supported by the interaction of WRN with p53 and MYC. p53 is a tumour suppressor protein and can regulate WRN exonuclease activity. ${ }^{113}$ Absence of WRN protein reduces the efficacy of p53 mediated cellular apoptosis, the key to its role in tumour suppression. ${ }^{114}$ Mice with both p53 and WRN mutations show accelerated tumorigenesis compared with mice with p53 mutation alone, ${ }^{115}$ suggesting a collaborative role for WRN with p53 in the prevention of tumour development. MYC is an oncoprotein which when overexpressed causes genomic instability and prevents cellular senescence. When MYC is added to WRN negative cells, the cells fail to proliferate like normal cells and express cellular markers of senescence. ${ }^{116}$ It appears that failure to undergo p53 induced apoptosis leads to a high risk of tumours in the syndrome, while failure to repair the genome results in apoptosis in other cell lines, leading to diabetes and degenerative disease.

\section{Thiamine responsive megaloblastic anaemia (Roger's syndrome)}

Thiamine responsive megaloblastic anaemia (TRMA; OMIM 249270 ) is a rare genetic syndrome where early onset megaloblastic anaemia (which responds to thiamine) is associated with diabetes and sensorineural deafness. ${ }^{117}$ The diabetes, which is insulin deficient in nature, is responsive to thiamine in some patients, although all seem to develop an insulin requirement in the long term. ${ }^{118}$ Deafness is unresponsive to thiamine. ${ }^{118}$ The condition has autosomal recessive inheritance, and three teams found mutations in a novel gene SLC19A2 in 1999 in a total of nine families. ${ }^{119-121}$ SLC19A2 encodes a membrane bound thiamine transporter protein known as THTR-1, ${ }^{121}$ and mutations causing TRMA have been shown to affect membrane targeting of THTR$1 .{ }^{122}{ }^{123}$ In TRMA cell lines, both cell and mitochondrion have a defect in the high affinity import of thiamine, ${ }^{124}$ but the significance of this mitochondrial defect is unclear, as the mitochondrion in TRMA individuals can import thiamine diphosphate (the active form of thiamine) normally. ${ }^{124}$ Thiamine is required for creation of thiamine pyrophosphate, a cofactor for several enzymes; one of these is transketolase, the rate limiting enzyme in the non-oxidative pentose shunt pathway for ribose synthesis, vital for nucleic acid production. Studies in fibroblast cell lines have shown that TRMA fibroblasts have normal ribose production in thiamine replete medium, but when exposed to thiamine deficient medium show a marked reduction in ribose synthesis concurrent with an increase in cellular apoptosis. ${ }^{125}$ This suggests that mutation in the high affinity thiamine transporter seen in TRMA leads directly to an increased rate of apoptosis in cells that have a high rate of nucleic acid synthesis-that is, those with high turnover such as the marrow, or those with high translation rates such a secretory $\beta$ cells.

\section{CONCLUSIONS}

The advances in molecular genetics and allied molecular sciences over the last 15 years have contributed greatly to our understanding of the normal workings of the $\beta$ cell, and the underlying causes for disruption of glucose homeostasis. The enormous advances brought about by the human genome project and new techniques such as RNA interference promise a continued accretion of knowledge over the coming years. Diabetes in all its forms seems to stem from three main mechanisms: apoptosis/ $\beta$ cell loss, insulin secretion defects, and insulin resistance. While previous attempts to unify the theories of type 1 and type 2 diabetes have proved to be flawed, abnormal apoptosis appears to be an exciting final common pathway in the development of diabetes, which may also explain the neurodegenerative and cancer susceptibility phenotypes seen in some syndromes associated with diabetes. Perhaps the most illuminating idea is that, far from being a catastrophic event, apoptosis is as much part of homeostatic mechanisms as are classical hormonal negative feedback loops. The study of rare diabetes syndromes gives us the chance to examine disruptions in individual components of the glucose homeostatic balance. This should lead to an understanding of how the mechanism works in health, and thus how minor alterations in the pathway can lead to glucose intolerance and diabetes. The combination of clinician, clinical geneticist, molecular scientist, and pharmacologist forms a powerful team for understanding the basis of diabetes pathogenesis and designing future treatments for this disease.

\section{ACKNOWLEDGEMENTS}

We would like to acknowledge the great help we received from Drs A Gloyn, E Gupta, J Minton, and C L Lendon in reviewing this paper and suggesting revisions. JRP is supported by a clinical research fellowship from Diabetes UK.

\section{Authors' affiliations \\ J R Porter, T G Barrett, Birmingham Children's Hospital, Birmingham,} UK

Competing interests: none declared

\section{REFERENCES}

1 World Health Organisation. Diabetes mellitus, Factsheet 138. Geneva: WHO, 2002.

2 Gloyn AL. The search for type 2 diabetes genes. Ageing Res Rev 2003;2:111-27.

3 Kelly MA, Mijovic CH, Barnett AH. Genetics of type 1 diabetes. Best Pract Res Clin Endocrinol Metab 2001;15:279-91. 
4 Dor Y, Brown J, Martinez OI, Melton DA. Adult pancreatic beta-cells are formed by self-duplication rather than stem-cell differentiation. Nature 2004;429:41-6.

5 Sakuraba H, Mizukami H, Yagihashi N, Wada R, Hanyu C, Yagihashi S. Reduced beta-cell mass and expression of oxidative stress-related DNA damage in the islet of Japanese type II diabetic patients. Diabetologia 2002;45:85-96

6 Butler AE, Janson J, Bonner-Weir S, Ritzel R, Rizza RA, Butler PC. Beta-cell deficit and increased beta-cell apoptosis in humans with type 2 diabetes. Diabetes 2003;52:102-10.

7 Kharroubi I, Ladriere L, Cardozo AK, Dogusan Z, Cnop M, Eizirik DL. Free fatty acids and cytokines induce pancreatic beta-cell apoptosis by different mechanisms: role of NF-kappaB and endoplasmic reticulum stress. Endocrinology 2004; 145:5087-96.

8 Owen KR, Stride A, Ellard S, Hattersley AT. Etiological investigation of diabetes in young adults presenting with apparent type 2 diabetes. Diabetes Care 2003;26:2088-93.

9 Frayling TM, Evans JC, Bulman MP, Pearson E, Allen L, Owen K, Bingham C, Hannemann M, Shepherd M, Ellard S, Hattersley AT. Beta-cell genes and diabetes: molecular and clinical characterization of mutations in transcription factors. Diabetes 2001;50(suppl 1):S94-100.

10 Barrett TG. Mitochondrial diabetes, DIDMOAD and other inherited diabetes syndromes. Best Pract Res Clin Endocrinol Metab 2001;15:325-43.

11 Pearson ER, Starkey BJ, Powell RJ, Gribble FM, Clark PM, Hattersley AT Genetic cause of hyperglycaemia and response to treatment in diabetes. Lancet 2003;362:1275-81.

12 Shepherd M, Pearson ER, Houghton J, Salt G, Ellard S, Hattersley AT. No deterioration in glycemic control in HNF-lalpha maturity-onset diabetes of the young following transfer from long-term insulin to sulphonylureas. Diabetes Care 2003;26:3191-2.

13 Mohamed-Ali V, Pinkney JH, Coppack SW. Adipose tissue as an endocrine and paracrine organ. Int J Obes Relat Metab Disord 1998;22:1 145-58.

14 OMIM. Online Mendelian Inheritance in Man. McKusick-Nathans Institute for Genetic Medicine, Johns Hopkins University, National Center for Biotechnology Information NLoMB, 2000

$15 \mathrm{Kim} \mathrm{HI}$, Ahn YH. Role of peroxisome proliferator-activated receptor-gamma in the glucose-sensing apparatus of liver and beta-cells. Diabetes 2004;53(suppl 1):S60-5.

16 Suter SL, Nolan JJ, Wallace P, Gumbiner B, Olefsky JM. Metabolic effects of new oral hypoglycemic agent CS-045 in NIDDM subjects. Diabetes Care 1992;15:193-203.

17 Ristow M, Muller-Wieland D, Pfeiffer A, Krone W, Kahn CR. Obesity associated with a mutation in a genetic regulator of adipocyte differentiation. N Engl J Med 1998:339:953-9.

18 Barroso I, Gurnell M, Crowley VE, Agostini M, Schwabe JW, Soos MA Maslen GL, Williams TD, Lewis H, Schafer AJ, Chatterjee VK, O'Rahilly S. Dominant negative mutations in human PPARgamma associated with severe insulin resistance, diabetes mellitus and hypertension. Nature 1999;402:880-3.

19 Hegele RA, Cao H, Frankowski C, Mathews ST, Leff T. PPARG F388L, a transactivation-deficient mutant, in familial partial lipodystrophy. Diabetes 2002:51:3586-90

20 Savage DB, Tan GD, Acerini CL, Jebb SA, Agostini M, Gurnell M, Williams RL, Umpleby AM, Thomas EL, Bell JD, Dixon AK, Dunne F, Boiani R Cinti S, Vidal-Puig A, Karpe F, Chatterjee VK, O'Rahilly S. Human metabolic syndrome resulting from dominant-negative mutations in the nuclear receptor peroxisome proliferator-activated receptor-gamma. Diabetes 2003;52:910-17.

21 Mori Y, Murakawa Y, Okada K, Horikoshi H, Yokoyama J, Tajima N, Ikeda Y. Effect of troglitazone on body fat distribution in type 2 diabetic patients. Diabetes Care 1999;22:908-12.

22 Altshuler D, Hirschhorn JN, Klannemark M, Lindgren CM, Vohl MC Nemesh J, Lane CR, Schaffner SF, Bolk S, Brewer C, Tuomi T, Gaudet D, Hudson TJ, Daly M, Groop L, Lander ES. The common PPARgamma Prol2Ala polymorphism is associated with decreased risk of type 2 diabetes. Nat Genet 2000;26:76-80.

23 Deeb SS, Fajas L, Nemoto M, Pihlajamaki J, Mykkanen L, Kuusisto J, Laakso M, Fujimoto W, Auwerx J. A Prol2Ála substitution in PPARgamma2 associated with decreased receptor activity, lower body mass index and improved insulin sensitivity. Nat Genet 1998;20:284-7.

24 Yamauchi T, Kamon J, Waki H, Murakami K, Motojima K, Komeda K, Ide T, Kubota N, Terauchi Y, Tobe K, Miki H, Tsuchida A, Akanuma Y, Nagai R, Kimura S, Kadowaki T. The mechanisms by which both heterozygous peroxisome proliferator-activated receptor gamma (PPARgamma) deficiency and PPARgamma agonist improve insulin resistance. J Biol Chem 2001;276:41245-54.

25 Cock TA, Houten SM, Auwerx J. Peroxisome proliferator-activated receptorgamma: too much of a good thing causes harm. EMBO Rep 2004;5:142-7.

26 Rosen ED, Sarraf P, Troy AE, Bradwin G, Moore K, Milstone DS, Spiegelman BM, Mortensen RM. PPAR gamma is required for the differentiation of adipose tissue in vivo and in vitro. Mol Cell 1999:4:611-17

27 Miles PD, Barak Y, He W, Evans RM, Olefsky JM. Improved insulin-sensitivity in mice heterozygous for PPAR-gamma deficiency. J Clin Invest 2000; 105:287-92

28 Barak Y, Nelson MC, Ong ES, Jones YZ, Ruiz-Lozano P, Chien KR, Koder A, Evans RM. PPAR gamma is required for placental, cardiac, and adipose tissue development. Mol Cell 1999;4:585-95.

29 Koutnikova H, Cock TA, Watanabe M, Houten SM, Champy MF, Dierich A, Auwerx J. Compensation by the muscle limits the metabolic consequences of lipodystrophy in PPAR gamma hypomorphic mice. Proc Natl Acad Sci USA 2003; 100:14457-62.

30 Gavrilova O, Haluzik M, Matsusue K, Cutson JJ, Johnson L, Dietz KR, Nicol CJ, Vinson C, Gonzalez FJ, Reitman ML. Liver peroxisome proliferatoractivated receptor gamma contributes to hepatic steatosis, triglyceride clearance, and regulation of body fat mass. J Biol Chem 2003;278:34268-76.

31 Hevener AL, He W, Barak Y, Le J, Bandyopadhyay G, Olson P, Wilkes J, Evans RM, Olefsky J. Muscle-specific Pparg deletion causes insulin resistance. Nat Med 2003;9:1491-7.

32 Norris AW, Chen L, Fisher SJ, Szanto I, Ristow M, Jozsi AC, Hirshman MF, Rosen ED, Goodyear $\amalg$, Gonzalez FJ, Spiegelman BM, Kahn CR. Musclespecific PPARgamma-deficient mice develop increased adiposity and insulin resistance but respond to thiazolidinediones. J Clin Invest 2003; 1 12:608-18.

33 Rosen ED, Kulkarni RN, Sarraf P, Ozcan U, Okada T, Hsu CH, Eisenman D, Magnuson MA, Gonzalez FJ, Kahn CR, Spiegelman BM. Targeted elimination of peroxisome proliferator-activated receptor gamma in beta cells leads to abnormalities in islet mass without compromising glucose homeostasis. Mol Cell Biol 2003;23:7222-9.

34 Kim HI, Cha JY, Kim SY, Kim JW, Roh KJ, Seong JK, Lee NT, Choi KY, Kim KS, Ahn YH. Peroxisomal proliferator-activated receptor-gamma upregulates glucokinase gene expression in beta-cells. Diabetes 2002;51:676-85

35 Kim HI, Kim JW, Kim SH, Cha JY, Kim KS, Ahn YH. Identification and functional characterization of the peroxisomal proliferator response element in rat GLUT2 promoter. Diabetes 2000:49:1517-24.

36 Akazawa S, Sun F, Ito M, Kawasaki E, Eguchi K. Efficacy of troglitazone on body fat distribution in type 2 diabetes. Diabetes Care 2000;23:1067-71.

37 Kelly IE, Han TS, Walsh K, Lean ME. Effects of a thiazolidinedione compound on body fat and fat distribution of patients with type 2 diabetes. Diabetes Care 1999:22:288-93

38 Reginato MJ, Bailey ST, Krakow SL, Minami C, Ishii S, Tanaka H, Lazar MA. A potent antidiabetic thiazolidinedione with unique peroxisome proliferatoractivated receptor gamma-activating properties. J Biol Chem 1998;273:32679-84.

39 Yamauchi T, Waki H, Kamon J, Murakami K, Motojima K, Komeda K, Miki H, Kubota N, Terauchi Y, Tsuchida A, Tsuboyama-Kasaoka N Yamauchi N, Ide T, Hori W, Kato S, Fukayama M, Akanuma Y, Ezaki O Itai A, Nagai R, Kimura S, Tobe K, Kagechika H, Shudo K, Kadowaki T. Inhibition of RXR and PPARgamma ameliorates diet-induced obesity and type 2 diabetes. J Clin Invest 2001;108:1001-13

40 Rocchi S, Picard F, Vamecq J, Gelman L, Potier N, Zeyer D, Dubuquoy L, Bac $P$, Champy MF, Plunket KD, Leesnitzer LM, Blanchard SG, Desreumaux $P$, Moras D, Renaud JP, Auwerx J. A unique PPARgamma ligand with potent insulin-sensitizing yet weak adipogenic activity. Mol Cell 2001;8:737-47.

41 Agarwal AK, Simha V, Oral EA, Moran SA, Gorden P, O'Rahilly S, Zaidi Z, Gurakan F, Arslanian SA, Klar A, Ricker A, White NH, Bindl L, Herbst K, Kennel K, Patel SB, Al Gazali L, Garg A. Phenotypic and genetic heterogeneity in congenital generalized lipodystrophy. J Clin Endocrinol Metab 2003;88:4840-7

42 Agarwal AK, Arioglu E, De Almeida S, Akkoc N, Taylor SI, Bowcock AM Barnes RI, Garg A. AGPAT2 is mutated in congenital generalized lipodystrophy linked to chromosome 9q34. Nat Genet 2002;31:21-3.

43 Agarwal AK, Barnes RI, Garg A. Genetic basis of congenital generalized lipodystrophy. Int J Obes Relat Metab Disord 2004;28:336-9.

44 Magre J, Delepine M, Khallouf E, Gedde-Dahl T, Van Maldergem L, Sobel E, Papp J, Meier M, Megarbane A, Bachy A, Verloes A, d'Abronzo FH, Seemanova E, Assan R, Baudic N, Bourut C, Czernichow P, Huet F, Grigorescu $F$, de Kerdanet $M$, Lacombe D, Labrune $P$, Lanza $M$, Loret $H$, Matsuda F, Navarro J, Nivelon-Chevalier A, Polak M, Robert JJ, Tric P, Tubiana-Rufi N, Vigouroux C, Weissenbach J, Savasta S, Maassen JA, Trygstad O, Bogalho P, Freitas P, Medina JL, Bonnicci F, Joffe BI, Loyson G, Panz VR, Raal FJ, O'Rahilly S, Stephenson T, Kahn CR, Lathrop M, Capeau J. Identification of the gene altered in Berardinelli-Seip congenital lipodystrophy on chromosome 11 lq13. Nat Genet 2001;28:365-70.

45 Van Maldergem L, Magre J, Khallouf TE, Gedde-Dahl T, Delepine M, Trygstad O, Seemanova E, Stephenson T, Albott CS, Bonnici F, Panz VR, Medina JL, Bogalho P, Huet F, Savasta S, Verloes A, Robert JJ, Loret H, de Kerdanet $M$, Tubiana-Rufi N, Megarbane A, Maassen J, Polak $M$, Lacombe D, Kahn CR, Silveira EL, d'Abronzo FH, Grigorescu F, Lathrop M, Capeau J, O'Rahilly S. Genotype-phenotype relationships in BerardinelliSeip congenital lipodystrophy. J Med Genet 2002;39:722-33.

46 Fu M, Kazlauskaite R, Baracho MF, Santos MG, Brandao-Neto J, Villares S, Celi FS, Wajchenberg BL, Shuldiner AR. Mutations in Gng3lg and AGPAT2 in Berardinelli-Seip congenital lipodystrophy and Brunzell syndrome: phenotype variability suggests important modifier effects. J Clin Endocrinol Metab 2004;89:2916-22.

47 Taylor SI, Kadowaki T, Kadowaki H, Accili D, Cama A, McKeon C. Mutations in insulin-receptor gene in insulin-resistant patients. Diabetes Care 1990;13:257-79.

48 Longo N, Wang Y, Smith SA, Langley SD, DiMeglio LA, Giannella-Neto D. Genotype-phenotype correlation in inherited severe insulin resistance. Hum Mol Genet 2002;11:1465-75.

49 Tritos NA, Mantzoros CS. Clinical review 97: Syndromes of severe insulin resistance. J Clin Endocrinol Metab 1998;83:3025-30.

50 Taylor SI, Samuels B, Roth J, Kasuga M, Hedo JA, Gorden P, Brasel DE, Pokora T, Engel RR. Decreased insulin binding in cultured lymphocytes from two patients with extreme insulin resistance. J Clin Endocrinol Metab 1982;54:919-30. 
51 Hone J, Accili D, Psiachou H, Alghband-Zadeh J, Mitton S, Wertheimer E, Sinclair L, Taylor SI. Homozygosity for a null allele of the insulin receptor gene in a patient with leprechaunism. Hum Mutat 1995;6:17-22.

52 Mercado MM, McLenithan JC, Silver KD, Shuldiner AR. Genetics of insulin resistance. Curr Diab Rep 2002;2:83-95.

53 Melis R, Pruett PB, Wang Y, Longo N. Gene expression in human cells with mutant insulin receptors. Biochem Biophys Res Commun 2003;307:1013-20.

54 Gloyn AL. Glucokinase (GCK) mutations in hyper- and hypoglycemia: maturity-onset diabetes of the young, permanent neonatal diabetes, and hyperinsulinemia of infancy. Hum Mutat 2003;22:353-62.

55 Hattersley AT, Turner RC, Permutt MA, Patel P, Tanizawa Y. Chiu KC, O'Rahilly S, Watkins PJ, Wainscoat JS. Linkage of type 2 diabetes to the glucokinase gene. Lancet 1992;339:1307-10.

56 Vionnet N, Stoffel M, Takeda J, Yasuda K, Bell GI, Zouali H, Lesage S, Velho G, Iris F, Passa P. Nonsense mutation in the glucokinase gene causes early-onset non-insulin-dependent diabetes mellitus. Nature 1992;356:721-2

57 Niolstad PR, Sovik O, Cuesta-Munoz A, Bjorkhaug L, Massa O, Barbetti F, Undlien DE, Shiota C, Magnuson MA, Molven A, Matschinsky FM, Bell GI Neonatal diabetes mellitus due to complete glucokinase deficiency. N Engl J Med 2001;344:1588-92.

58 Niolstad PR, Sagen JV, Bjorkhaug L, Odili S, Shehadeh N, Bakry D, Sarici SU, Alpay F, Molnes J, Molven A, Sovik O, Matschinsky FM. Permanent neonatal diabetes caused by glucokinase deficiency: inborn error of the glucose-insulin signaling pathway. Diabetes 2003;52:2854-60.

59 Glaser B, Kesavan P, Heyman M, Davis E, Cuesta A, Buchs A, Stanley CA, Thornton PS, Permutt MA, Matschinsky FM, Herold KC. Familial hyperinsulinism caused by an activating glucokinase mutation. N Engl J Med 1998;338:226-30

60 Owen K HA. Maturity-onset diabetes of the young: from clinical description to molecular genetic characterization. Best Pract Res Clin Endocrinol Metab 2001;15:309-23.

61 Thomas $\mathbf{P}, \mathrm{Ye} Y$, Lightner E. Mutation of the pancreatic islet inward rectifier Kir6.2 also leads to familial persistent hyperinsulinemic hypoglycemia of infancy. Hum Mol Genet 1996:5:1809-12.

62 Thomas PM, Cote GJ, Wohllk N, Haddad B, Mathew PM, Rabl W, AguilarBryan L, Gagel RF, Bryan J. Mutations in the sulfonylurea receptor gene in familial persistent hyperinsulinemic hypoglycemia of infancy. Science 1995;268:426-9.

63 Stanley CA. Hyperinsulinism/hyperammonemia syndrome: insights into the regulatory role of glutamate dehydrogenase in ammonia metabolism. Mol Genet Metab 2004;81(suppl 1):S45-51.

64 Cuesta-Munoz AL, Huopio H, Otonkoski T, Gomez-Zumaquero JM, NantoSalonen K, Rahier J, Lopez-Enriquez S, Garcia-Gimeno MA, Sanz P, Soriguer FC, Laakso M. Severe persistent hyperinsulinemic hypoglycemia due to a de novo glucokinase mutation. Diabetes 2004;53:2164-8.

65 Aguilar-Bryan L, Clement JP, Gonzalez G, Kunjilwar K, Babenko A, Bryan J. Toward understanding the assembly and structure of KATP channels. Physiol Rev 1998;78:227-45.

66 Gloyn AL, Pearson ER, Antcliff JF, Proks P, Bruining GJ, Slingerland AS, Howard N, Srinivasan S, Silva JM, Molnes J, Edghill EL, Frayling TM, Temple IK, Mackay D, Shield JP, Sumnik Z, van Rhijn A, Wales JK, Clark P, Gorman S, Aisenberg J, Ellard S, Niolstad PR, Ashcroft FM, Hattersley AT. Activating mutations in the gene encoding the ATP-sensitive potassiumchannel subunit Kir6.2 and permanent neonatal diabetes. N Engl J Med 2004;350:1838-49

67 Sagen JV, Raeder H, Hathout E, Shehadeh N, Gudmundsson K, Baevre H, Abuelo D, Phornphutkul C, Molnes J, Bell Gl, Gloyn AL, Hattersley AT, Molven A, Sovik O, Niolstad PR. Permanent neonatal diabetes due to mutations in KCNJ11 encoding Kir6. 2: patient characteristics and initial response to sulfonylurea therapy, Diabetes 2004;53:2713-18.

68 Gloyn AL, Cummings EA, Edghill EL, Harries LW, Scott R, Costa T, Temple IK, Hattersley AT, Ellard S. Permanent neonatal diabetes due to paternal germline mosaicism for an activating mutation of the KCNJ11 Gene encoding the Kir6.2 subunit of the beta-cell potassium adenosine triphosphate channel. J Clin Endocrinol Metab 2004;89:3932-5.

69 Bernard-Kargar C, Ktorza A. Endocrine pancreas plasticity under physiological and pathological conditions. Diabetes 2001;50/suppl 1):S30-5.

70 Mandrup-Poulsen T. Apoptotic signal transduction pathways in diabetes. Biochem Pharmacol 2003;66:1433-40

71 Wobser H, Dussmann $H$, Kogel D, Wang $H$, Reimertz C, Wollheim CB, Byrne MM, Prehn JH. Dominant-negative suppression of HNF-1 alpha results in mitochondrial dysfunction, INS-1 cell apoptosis, and increased sensitivity to ceramide-, but not to high glucose-induced cell death. J Biol Chem 2002;277:6413-21.

72 Ma D, Shield JPH, Dean W, Leclerc I, Knauf C, Burcelin R, Rutter GA, Kelsey G. Impaired glucose homeostasis in transgenic mice expressing the human transient neonatal diabetes mellitus locus, TNDM. J Clin Invest 2004; 114:339-48

73 Temple IK, Gardner RJ, Mackay DJ, Barber JC, Robinson DO, Shield JP. Transient neonatal diabetes: widening the understanding of the etiopathogenesis of diabetes. Diabetes 2000;49:1359-66.

74 Kamiya M, Judson H, Okazaki Y, Kusakabe M, Muramatsu M, Takada S, Takagi N, Arima T, Wake N, Kamimura K, Satomura K, Hermann R, Bonthron DT, Hayashizaki Y. The cell cycle control gene ZAC/PLAGL1 is imprinted - a strong candidate gene for transient neonatal diabetes. Hum Mol Genet 2000;9:453-60.

75 Atkinson MA, Eisenbarth GS. Type 1 diabetes: new perspectives on disease pathogenesis and treatment. Lancet 2001;358:221-9.
76 Maedler K, Sergeev P, Ris F, Oberholzer J, Joller-Jemelka HI, Spinas GA, Kaiser N, Halban PA, Donath MY. Glucose-induced beta cell production of IL-1 beta contributes to glucotoxicity in human pancreatic islets. J Clin Invest 2002;110:851-60.

77 Bin-Abbas B, Al Mulhim A, Al Ashwal A. Wolcott-Rallison syndrome in two siblings with isolated central hypothyroidism. Am J Med Genet 2002;111:187-90.

78 Delepine M, Nicolino M, Barrett T, Golamaully M. Lathrop GM, Julier C. EIF2AK3, encoding translation initiation factor 2-alpha kinase 3, is mutated in patients with Wolcott-Rallison syndrome. Nat Genet 2000;25:406-9.

79 Harding HP, Ron D. Endoplasmic reticulum stress and the development of diabetes: a review. Diabetes 2002;51(suppl 3):S455-61

$80 \mathrm{Ma} \mathrm{K}$, Vattem KM, Wek RC. Dimerization and release of molecular chaperone inhibition facilitate activation of eukaryotic initiation factor-2 kinase in response to endoplasmic reticulum stress. J Biol Chem 2002;277: 18728-35.

81 Brickwood S, Bonthron DT, Al Gazali LI, Piper K, Hearn T, Wilson DI, Hanley NA. Wolcott-Rallison syndrome: pathogenic insights into neonatal diabetes from new mutation and expression studies of EIF2AK3. J Med Genet 2003;40:685-9.

82 Biason-Lauber A, Lang-Muritano M, Vaccaro T, Schoenle EJ. Loss of kinase activity in a patient with Wolcott-Rallison syndrome caused by a novel mutation in the EIF2AK3 gene. Diabetes 2002:51:2301-5

83 Vaxillaire $M$, Benmezroua $Y$, Durand $E$, Vasseur $F$, Froguel P. No evidence for diabetes-associated mutations of PEK/EIF2AK3 gene in French patients with early-onset type II diabetes. Diabetologia 2001;44:786.

84 Barrett TG, Bundey SE, Macleod AF. Neurodegeneration and diabetes: UK nationwide study of Wolfram (DIDMOAD) syndrome. Lancet 1995; 346:1458-63

85 Khanim F, Kirk J, Latif F, Barrett TG. WFS1/Wolframin Mutations, Wolfram syndrome and Associated Diseases. Hum Mutat 2001;17:357-67.

86 Inoue H, Tanizawa Y, Wasson J, Behn P, Kalidas K, Bernal-Mizrachi E, Mueckler M, Marshall H, Donis-Keller H, Crock P, Rogers D, Mikuni M, Kumashiro H, Higashi K, Sobue G, Oka Y, Permutt MA. A gene encoding a transmembrane protein is mutated in patients with diabetes mellitus and optic atrophy (Wolfram syndrome). Nat Genet 1998;20:143-8.

87 Strom TM, Hortnagel K, Hofmann S, Gekeler F, Scharfe C, Rabl W, Gerbitz KD, Meitinger T. Diabetes insipidus, diabetes mellitus, optic atrophy and deafness (DIDMOAD) caused by mutations in a novel gene (wolframin) coding for a predicted transmembrane protein. Hum Mol Genet 1998:7:2021-8.

88 Osman AA, Saito M, Makepeace C, Permutt MA, Schlesinger P, Mueckler M. Wolframin expression induces novel ion channel activity in endoplasmic reticulum membranes and increases intracellular calcium. J Biol Chem 2003;278:52755-62.

89 Ishihara H, Takeda S, Tamura A, Takahashi R, Yamaguchi S, Takei D, Yamada T, Inoue H, Soga H, Katagiri H, Tanizawa Y, Oka Y. Disruption of the WFS1 gene in mice causes progressive beta-cell loss and impaired stimulus-secretion coupling in insulin secretion. Hum Mol Genet 2004; 13:1159-70.

90 Minton JA, Hattersley AT, Owen K, McCarthy MI, Walker M, Latif F, Barrett T, Frayling TM. Association studies of genetic variation in the WFS1 gene and type 2 diabetes in UK populations. Diabetes 2002;51:1287-90.

91 Monros E, Molto MD, Martinez F, Canizares J, Blanca J, Vilchez JJ, Prieto F, de Frutos $R$, Palau $F$. Phenotype correlation and intergenerational dynamics of the Friedreich ataxia GAA trinucleotide repeat. Am J Hum Genet 1997;61:101-10.

92 Shaw J, Lichter P, Driesel AJ, Williamson R, Chamberlain S. Regional localisation of the Friedreich ataxia locus to human chromosome 9q13---q21.1. Cytogenet Cell Genet 1990;53:221-4.

93 Campuzano V, Montermini L, Lutz Y, Cova L, Hindelang C, Jiralerspong S, Trottier Y, Kish SJ, Faucheux B, Trouillas P, Authier FJ, Durr A, Mandel JL, Vescovi A, Pandolfo $M$, Koenig M. Frataxin is reduced in Friedreich ataxia patients and is associated with mitochondrial membranes. Hum Mol Genet 1997;6:1771-80.

94 Campuzano V, Montermini L, Molto MD, Pianese L, Cossee M, Cavalcanti F, Monros E, Rodius F, Duclos F, Monticelli A. Friedreich's ataxia: autosomal recessive disease caused by an intronic GAA triplet repeat expansion. Science 1996;271:1423-7.

95 McCabe DJ, Ryan F, Moore DP, McQuaid S, King MD, Kelly A, Daly K, Barton DE, Murphy RP. Typical Friedreich's ataxia without GAA expansions and GAA expansion without typical Friedreich's ataxia. J Neurol 2000;247:346-55

96 Durr A, Cossee M, Agid Y, Campuzano V, Mignard C, Penet C, Mandel JL, Brice A, Koenig M. Clinical and genetic abnormalities in patients with Friedreich's ataxia. N Engl J Med 1996;335:1169-75.

97 Sakamoto N, Ohshima K, Montermini L, Pandolfo M, Wells RD. Sticky DNA, a self-associated complex formed at long GAA*TTC repeats in intron 1 of the frataxin gene, inhibits transcription. J Biol Chem 2001;276:27171-7.

98 Lodi R, Cooper JM, Bradley JL, Manners D, Styles P, Taylor DJ, Schapira AH Deficit of in vivo mitochondrial ATP production in patients with Friedreich ataxia. Proc Natl Acad Sci USA 1999;96:11492-5.

99 Wong A Yang J, Cavadini P, Gellera C, Lonnerdal B, Taroni F, Cortopassi G. The Friedreich's ataxia mutation confers cellular sensitivity to oxidant stress which is rescued by chelators of iron and calcium and inhibitors of apoptosis. Hum Mol Genet 1999;8:425-30.

100 Tan G, Chen LS, Lonnerdal B, Gellera C, Taroni FA, Cortopassi GA. Frataxin expression rescues mitochondrial dysfunctions in FRDA cells. Hum Mol Genet 2001;10:2099-107.

101 Ristow M, Mulder H, Pomplun D, Schulz TJ, Muller-Schmehl K, Krause A, Fex M, Puccio H, Muller J, Isken F, Spranger J, Muller-Wieland D, 
Magnuson MA, Mohlig M, Koenig M, Pfeiffer AF. Frataxin deficiency in pancreatic islets causes diabetes due to loss of beta cell mass. J Clin Invest 2003; 1 12:527-34

102 Hebinck J, Hardt C, Schols L, Vorgerd M, Briedigkeit L, Kahn CR, Ristow M. Heterozygous expansion of the GAA tract of the X25/frataxin gene is associated with insulin resistance in humans. Diabetes 2000;49:1604-7.

103 Hart LM, Ruige JB, Dekker JM, Stehouwer CD, Maassen JA, Heine RJ. Altered beta-cell characteristics in impaired glucose tolerant carriers of a GAA trinucleotide repeat polymorphism in the frataxin gene. Diabetes 1999;48:924-6.

104 Ristow M, Giannakidou E, Hebinck J, Busch K, Vorgerd M, Kotzka J, Knebel B, Mueller-Berghaus J, Epplen C, Pfeiffer A, Kahn CR, Doria A, Krone W, Mueller-Wieland D. An association between NIDDM and a GAA trinucleotide repeat polymorphism in the $\mathrm{X} 25$ /frataxin (Friedreich's ataxia) gene. Diabetes 1998;47:851-4.

105 Dupont S, Dubois D, Vionnet N, Boitard C, Caillat-Zucman S, Timsit J, Froguel $P$. No association between the Friedreich's ataxia gene and NIDDM in the French population. Diabetes 1998:47:1654-6.

106 Chen L, Oshima J. Werner Syndrome. J Biomed Biotechnol 2002;2:46-54

107 Yamada K, Ikegami H, Yoneda H, Miki T, Ogihara T. All patients with Werner's syndrome are insulin resistant but only those who also have impaired insulin secretion develop overt diabetes. Diabetes Care 1999;22:2094.

108 Opresko PL, Cheng WH, von Kobbe C, Harrigan JA, Bohr VA. Werner syndrome and the function of the Werner protein; what they can teach us about the molecular aging process. Carcinogenesis 2003;24:791-802.

109 Yu CE, Oshima J, Fu YH, Wijsman EM, Hisama F, Alisch R, Matthews S, Nakura J, Miki T, Ouais S, Martin GM, Mulligan J, Schellenberg GD. Positional Cloning of the Werner's Syndrome Gene. Science 1996;272:258-62.

110 Oshima J. The Werner syndrome protein: an update. Bioessays 2000;22:894-901

111 Kamath-Loeb AS, Johansson E, Burgers PM, Loeb LA. Functional interaction between the Werner Syndrome protein and DNA polymerase delta. Proc Natl Acad Sci USA 2000;97:4603-8.

112 Kamath-Loeb AS, Loeb LA, Johansson E, Burgers PM, Fry M. Interactions between the Werner syndrome helicase and DNA polymerase delta specifically facilitate copying of tetraplex and hairpin structures of the $d(C G G) n$ trinucleotide repeat sequence. J Biol Chem 2001;276:16439-46.
113 Brosh RM, Karmakar P, Sommers JA, Yang Q, Wang XW, Spillare EA Harris CC, Bohr VA. p53 Modulates the exonuclease activity of Werner syndrome protein. J Biol Chem 2001;276:35093-102.

114 Spillare EA, Robles Al, Wang XW, Shen JC, Yu CE, Schellenberg GD, Harris CC. p53-mediated apoptosis is attenuated in Werner syndrome cells. Genes Dev 1999;13:1355-60.

115 Lebel M, Cardiff RD, Leder P. Tumorigenic effect of nonfunctional p53 or p21 in mice mutant in the Werner syndrome helicase. Cancer Res 2001;61:1816-19.

116 Grandori C, Wu KJ, Fernandez P, Ngouenet C, Grim J, Clurman BE Moser MJ, Oshima J, Russell DW, Swisshelm K, Frank S, Amati B, DallaFavera R, Monnat RJ. Werner syndrome protein limits MYC-induced cellular senescence. Genes Dev 2003;17:1569-74.

117 Rogers LE, Porter FS, Sidbury JB. Thiamine-responsive megaloblastic anemia. J Pediatr 1969:74:494-504.

118 Ozdemir MA, Akcakus M, Kurtoglu S, Gunes T, Torun YA. TRMA Syndrome (thiamine responsive megaloblastic anemia):a case report and review of the literature. Pediatr Diabetes 2002;3:205-9.

119 Diaz GA, Banikazemi M, Oishi K, Desnick RJ, Gelb BD. Mutations in a new gene encoding a thiamine transporter cause thiamine-responsive megaloblastic anaemia syndrome. Nat Genet 1999;22:309-12.

120 Fleming JC, Tartaglini E, Steinkamp MP, Schorderet DF, Cohen N, Neufeld EJ. The gene mutated in thiamine-responsive anaemia with diabetes and deafness (TRMA) encodes a functional thiamine transporter. Nat Genet 1999:22:305-8.

121 Labay V, Raz T, Baron D, Mandel H, Williams H, Barrett T, Szargel R, McDonald L, Shalata A, Nosaka K, Gregory S, Cohen N. Mutations in SLC19A2 cause thiamine-responsive megaloblastic anaemia associated with diabetes mellitus and deafness. Nat Genet 1999;22:300-4.

122 Baron D, Assaraf YG, Cohen N, Aronheim A. Lack of plasma membrane targeting of a G172D mutant thiamine transporter derived from Rogers syndrome family. Mol Med 2002;8:462-74.

123 Subramanian VS, Marchant JS, Parker I, Said HM. Cell biology of the human thiamine transporter-1 (hTHTR1). Intracellular trafficking and membrane targeting mechanisms. J Biol Chem 2003;278:3976-84.

124 Song Q, Singleton CK. Mitochondria from cultured cells derived from normal and thiamine-responsive megaloblastic anemia individuals efficiently import thiamine diphosphate. BMC Biochem 2002;3:8.

125 Boros LG, Steinkamp MP, Fleming JC, Lee WN, Cascante M, Neufeld EJ. Defective RNA ribose synthesis in fibroblasts from patients with thiamineresponsive megaloblastic anemia (TRMA). Blood 2003;102:3556-61.

\section{1 th European Forum on Quality Improvement in Health Care}

26-28 April 2006, Prague, Czech Republic

For further information please go to: www.quality.bmipg.com

Book early to benefit from a discounted delegate rate 